\title{
Criminal Acts Committed With a Common Intention and Under Intoxication: A Case Scenario Highlighting Their Legal Implications
}

Ariyarathna HTDW*

Department of Forensic Medicine, Faculty of Medical Sciences, University of Sri Jayewardenepura. Sri Lanka.

\begin{abstract}
The case under discussion highlights two important laws in the Penal Code (PC) of Sri Lanka namely, section 32, liability for actions/ offences carried out with common intention, and section 78 and 79, offences done under a state of intoxication. An infuriated first accused who had started a brawl with the victim over a fence and in the midst of the struggle had asked the second accused to bring him a 'cement' stone to hit the victim with. The second accused had promptly found and handed the first accused a heavy stone by which the victim was forcefully assaulted. The victim died as a result of blunt force trauma with cranio-cerebral injuries. The indictment was issued against both the first and the second accused under the Section 32 (chapter II, general explanations), of the Penal Code making both the accused liable as if the act was done by the one and same person. The second accused tried to defend himself stating that he was under the influence of alcohol and pleaded that he was not in a state to thinking clearly because he was forcefully drunk by the first accused and he defended under the Section 78 of Penal Code (Ordinance No. 2 of 1883). The author performed the medico-legal investigation of the deceased and the second accused. In this article, the importance of having the legal knowledge surrounding this scenario is discussed.
\end{abstract}

Keywords: Common intention in criminal offences, insanity with intoxication, common defences, forensic pathologist

Received: 10 May 2021, Revised version accepted: 18 June 2021, Published: 30 June 2021. *Corresponding author: Ariyarathna HTDW, $\bigotimes$ Email: ariyaratna@sjp.ac.lk (D) https://orcid.org/0000-0002-4266-5508

Cite this article as: Ariyarathna HTDW. Criminal Acts Committed With a Common Intention and Under Intoxication: A Case Scenario Highlighting Their Legal Implications. Medico-Legal Journal of Sri Lanka, 2021;9(1):20-23.

DOI: http://doi.org/10.4038/mljsl.v9i1.7428

Copyright: @ 2019 with the Medico-legal Journal of Sri Lanka.

This is an open-access article distributed under the terms of the Creative Commons Attribution 4.0 International License, which permits unrestricted use, distribution, and reproduction in any medium provided the original author and source are credited.

\section{Introduction}

Performing medico-legal investigations in cases of suspected homicide and respective accused is one of vital duties of forensic pathologists. In this work, the author has come across that there is a lack of the relevant legal knowledge among - recruits and trainees, in this field of forensic medicine as a whole. It is not the duty of the forensic pathologists to interpret the law, however, it is always prudent to equip ourselves with the body of legal knowledge surrounding the cases.

A detailed history from the police is necessary before commencing any medico-legal investigation. The first investigating officers i.e. police are the ones who institute charges in the prosecution of the cases. We have to obtain these details from the police and determine why they intend to produce an accused before the Judicial Medical Officer. The complete details, in cases of deaths, are also mandatory as it always helps to address the medicolegal issues surrounding the cases. In the case under discussion, the importance of examination of the issue of a state of mind under influence of alcohol and the surrounding circumstances are very important at the time of examination of the accused by a forensic pathologist. According to the author's personal experience, at least $40 \%$ of cases of homicides have been inflicted by more than one accused. Therefore, the likelihood to have charges brought under section 32 of the Penal Code is considered most if not always probable in daily encountering cases.[1]

\section{Case report}

The deceased had been having an ongoing long term dispute over a common boundary with the next- door neighbour. Both have had several previous quarrels regarding this fence and therefore both the first accused and the deceased had not been on good terms with each other. While the neighbour-the first accused, was having a "drink" with one of his friends (the second accused), the deceased had started to trim the fence in dispute, which act completely angered the first accused. So he ran out 
of the house and had started a brawl with the deceased which had the deceased fall to the ground. The first accused had then instructed the second accused to bring a 'cement brick' to kill him. The second accused had responded to this request and did exactly what was asked. Instantly, he had thrown the heavy cement brick onto the head of the deceased rendering him unconscious. By the time the victim was transferred to the hospital, he had passed away. The post-mortem examination revealed multiple fractures to his face and head. The cause of death was determined as cranio-cerebral injuries inflicted by heavy blunt force trauma.

The second accused was also produced before the forensic pathologist after 24 hours of the incident as an alleged assailant. The second assailant mentioned that he did not want to take part with the first assailant to kill the victim at all. $\mathrm{He}$ further mentioned that he was under the influence of alcohol and he was unaware of what he was doing. He mentioned that he never intended to kill the victim. Furthermore, he added that he had come to the place of his friend to find some herbal medicines for his wife. He vehemently mentioned that the first accused had forced him to drink with him as it was his birthday. There were no injuries compatible to indicate forceful ingestion of alcohol such as circumoral injuries, grab marks, etc. There were no alcohol smell or signs and symptoms to indicate that he was under the influence of alcohol. He was conscious and rational. No history of any physical or psychiatric illnesses was found.

\section{Discussion}

As a practice, the author studies the legal background to any such homicide before appearing in court for the trial. It revealed that the Attorney General had indicted the first and second accused according to section 32 under the general explanations of Chapter II of the Penal Code: "Whenever an act, which is criminal only because of its being done with a criminal knowledge or intention, is done by several persons, each of such persons who joins in the act with such knowledge or intention is liable for the act in the same way as if the act were done by him alone with that knowledge or intention".[1,3]

According to law only the person who commits the act/harm is be liable for such harm done and no other. However, there are exceptions to this law. When a person intentionally joins another in committing a crime to whatever degree, the person who so joins or assists, is held equally liable for the offence so committed. However, it is emphasized that this criminal liability should be exercised with caution since otherwise, it could encompass a wider range of persons. The extent of participation may be active or mere contributive. At times, it has been proved that the mere but active presence is enough to be considered culpable under section 32.[2,3] When there is more than one accused and if the evidence indicates of sharing of the common murderous intention with a common object in the given scenario the section mentioned above may be applicable. It is immaterial whether the actus reus is great or small. Since there is a murderous intention in common, Section 32 is still applicable. [4] In the case under discussion, the first accused had mentioned the intention by saying 'let us kill him' and had ordered his friend, the second accused to bring a cement brick to kill him indicating a common intention.

Be that as it may, the second accused had put up his defence stating the fact under Section 78 of the general exceptions in Chapter IV and it states “ nothing is an offence which is done by a person who, at the time of doing it, is, by the reason of intoxication, incapable of knowing the nature of the act or that he is doing what is either wrong or contrary to law: Provided that the thing which intoxicated him was administered to him without his knowledge or against his will'.[1,5] The second accused had mentioned that he was drunk, and only because he was forced by the first accused to take alcohol, and therefore he was never conscious about what the first accused was telling or what he was doing. In other words, he had mentioned that he was under the alcohol intoxication and he was unaware and incapable of understanding his actions (or about subsequent consequences) that he was doing.

He had further mentioned that he rarely drank and was only visiting the house to collect some herbal medicine. The first accused had already been under the influence of alcohol by the time the second accused got to his house. He had told him that his refusal to drink would end their friendship. The second accused mentioned that the first accused did not let him leave the house by closing all doors. He had also tried to assault him with a heavy pole. The second accused also mentioned that he hadn't had any confrontations beforehand with the deceased.

The next important aspect is how to decide about the nature of force applied to get consumed alcohol/drugs against one's will. Unless the drink is given secretly without any detectable smell or taste usually a person knows what he drinks. So, there are two components to be considered in a case of involuntary intoxication of liquor: the liquor either should be given without the knowledge of the person or else by force or coercion. According to the case Burrows v. State, Arizona Supreme Court 297 P. 1029 (1931), Mr. Milton Drucker was killed by a college student (defendant) Richard N. Burrows while providing him a lift in his car. The student mentioned that, Milton Drucker who was already in 
an advanced state of intoxication, insisted that he would be left by the side of the road (they were traveling in a dessert) unless he consumed intoxicating liquor (vehemently urged). According to him, since he "feared being left alone in the desert" he drank liquor. During the travel Burrows had shot Milton and he mentioned that he was unaware of his act until afterwards. Burrows declared about the involuntary intoxication at the trial though he was convicted of murder and later it had been appealed.[5,7] According to Professor GL Peiris, the amount of force should be in such an amount that a normal person cannot withstand.[7] The second accused was free from any physical injuries to indicate any forceful ingestion of alcohol by the first assailant. He agreed that he was under the influence of alcohol resulting in unsoundness of his mind at that time too.

In contrast to the involuntary intoxication as described in this case, section 79 of the Penal Code deals with voluntary intoxication. Under this section, a drunkard is considered as - a sober person by considering the voluntary nature of the intoxication. Nevertheless, it is the responsibility of the accused to prove to the court that he was in a state of intoxication and he was unaware of the act that he was doing. In the case of Marikkar MA v. The Queen, it is explained that the necessity is only to prove that the accused was in a "state of intoxication" not only by alcohol but by any other substances such as within the scope of intoxication such as ganja.[8]

The important case laws that are to be mentioned in relation to these legal concepts that are dealt in this case reports namely the common intention and involuntary intoxication by liquor are discussed below. In a case of murder, the King v. Velaiden drunkenness was put forwarded as a defence. The defence should prove that due to the intoxication he was in a state that he was unable to form the necessary intention to commit the crime. What is the reason behind the intoxication that qualifies it to be considered as a defence in the law? There should be two elements to prove a criminal act, actus reus and the mensrea. (Knowledge and intention are different instances of mensrea) Intoxication impairs a person's ability to reason and form an intention. So in the above case the defence of drunkenness was put forward though the appeal was dismissed.[9]

In the case the King v. Rengasamy, a murder committed while in a state of drunkenness due to self-induced intoxication was discussed. Rengasamy in a state of self-induced intoxication, attacked the deceased man repeatedly with a club.[10] According to the Dayaratne v. The Republic of Sri Lanka had set up a plea of voluntary intoxication. [11] Piyathilaka and 2 Others vs. Republic of Sri
Lanka held that an accused may be susceptible to be provoked, if he was under the influence of liquor. [12] In addition to that in the same case, it was held that the mere presence is not sufficient to maintain a charge in the context of common intention.[3]

As per the common intention, the following case reports are to be mentioned. In the case under Attorney General v. Munasinghe, it was mentioned about a jointly committed crime and also about the extent of the liability.[13] It has been clearly mentioned that mere presence is not sufficient to maintain a charge on the basis of "Common Intention". But the second accused in the case had done more than solely being "present" at the incident since he had helped the act by providing a heavy stone. In other words it is necessary to prove a "participatory presence" along with a "similar intention" to cause harm by all the participants in a given incident.

The common intention in murderous behavior and the state of intoxication causing "insanity" are important legal concepts that a forensic pathologist must be fully aware of as illustrated above. Unless the forensic pathologist is unaware of the differences of the laws, he would not obtain a proper history and then would not do a proper clinical examination to address the involuntary nature of the alcohol consumption. When there is more than one alleged accused, additional emphasis is to be paid during the postmortem examination because many questions will be posted during the trial as it is necessary to punish accordingly proven with the medical evidence in addition to the hearsay evidence. The awareness of the legal background is helpful to investigate a case medico-legally, to render a better standard of service.

The author highlights the necessity of the application of concepts of law into their everyday practice to cater fairly and impartially to the citizens. Forensic pathologists should essentially be well versed in the laws that the author discusses in this scenario since they are not rare laws but the most commonly practiced areas of law without an adequate emphasis in the arena of forensic medicine.

\section{Conclusions}

As the prosecution, a forensic pathologist has to provide their evidence at murder trials for alleged assailants. From the point of history, deduction of such evidence is the responsibility of the forensic pathologist and in doing so, collecting facts based on the legal background of a given case should be made the standard practice as it helps to gather medical evidence objectively and prudently.

The stipulation of the way a defence council might think about a given case is very helpful to gather 
evidence and then to direct the medico-legal investigations in prudently.

The scenario illustrated above made the author think in-depth, about two important sections of the Penal Code of Sri Lanka, namely, the Section 32, the Sections 78 and 79 common intention and the incapacity or lack of knowledge under involuntary and voluntary intoxication respectively. The author assumes that the second accused is unlikely to have convinced his defence indicating involuntary intoxication under the section 78 of the Penal Code and he probably would have been charged based on section 32 of the Penal Code considering the common intention.

\section{Disclosure statement}

Conflicts of interests: The author declares that she has no conflicts of interest.

Funding: None

\section{References}

1. Penal Code (Ordinance No. 2 of 1883). Sri Lanka: Penal Code [Sri Lanka]. Available from: https://www.refworld.org/docid/4c03e2af2.html [Accessed 8th September 2020]

2. Yeo S. "Common intention in the Indian Penal Code: Insights from Singapore". Journal of the Indian Law Institute, vol. 50, no. 4, 2008, pp. 640-55. JSTOR, www.jstor.org/stable/ 43952182. [Accessed 8th September 2021].

3. Piyathilaka and 2 Others v. Republic of Sri Lanka - SLR - 141, Vol 2 of 1996 [1996] LKCA 25; (1996) 2 Sri LR 141 (4 April 1996). https://www.lawnet.gov.lk/wp-content/uploads /2016/11/023-SLLR-SLLR-1996-V-2-

Piyathilaka-and-2-Others-v.-Republic-Of-SriLanka.pdf [Accessed 4 June 2021].

4. Sri Lanka Law Reports. The attorney General Vs. Potta-Naufer and others- Ambepitiya murder case. 015-Sllr-Sllr-2007-V-2. Available from: https://www.lawnet.gov.lk/wp-content /uploads/2016/11/015-SLLR-SLLR-2007-V-2THE. 2007.p 144-202. https://www. lawnet.gov.lk/wp-content/uploads /2016/11/015 -SLLR-SLLR-2007-V-2-The-Attorney-Generalv.-Potta-Nauffer-And-Others-AmbilipitiyaMurder-Case. pdf [Accessed 8th Sep 2021].

5. Burrows v. State, 297 P. 1029 (1931): Case Brief Summary. Quimbee. [cited 2021 Jun 17]. Available from: https://www.quimbee.com/ cases/burrows-v-state

6. Burrows v. State | Case Brief for Law School | LexisNexis [Internet]. Community. [cited 2021 Jun 17]. Available from: https://www.lexisnexis. $\mathrm{com} /$ community/casebrief/p/casebrief-burrowsv-state

7. Peiris GL General Principles of criminal liability in Sri Lanka: a comprehensive analysis.
Colombo: Stamford Lake (Pvt) Ltd;2018 (7th reprint). pp. 184-9

8. MAM Marikkar, Appellant, and The Queen, Respondent CCA No. 86 of 1968, with application no.126 S.C. 170 of 1968-11. C. Puttalam, 3943. https:/www.lawnet.gov.lk/wpcontent/uploads/2016/11/011-NLR-NLR-V-72M.-A.-MARIKKAR-Appellant-and-THEQUEEN-Respondent.pdf [Accessed 18 June 2021].

9. King v. Velaiden - NLR - 409 of 48 [1947] LKHC 44; [1947] 32; (1947) 48 NLR 409 (8 September 1947) http://www.commonlii.org/ cgi-bin/disp.pl/lk/cases/LKHC/1947/44.html? stem $=0 \&$ synonyms $=0 \&$ query $=$ Intoxication [Accessed 4 June 2021].

10. King v. Rengasamy- NLR - 438 of 25 [1924] LKHC 6; [1924] 15; (1924) 25 NLR 438 (2 June 1924) http://www.commonlii.org/cgi-bin/disp. $\mathrm{pl} / \mathrm{lk} /$ cases/LKHC/1924/6.html?stem=0\&synony $\mathrm{ms}=0 \&$ query $=$ Intoxication [Accessed 18 June 2021].

11. Dayaratne v. The Republic of Sri Lanka - SLR 226, Vol 2 of 1990 [1990] LKCA 29; (1990) 2 Sri LR $226 \quad$ (14 March 1990) http://www.commonlii.org/cgi-bin/disp.pl/lk/ cases $/$ LKCA/1990/29.html?stem=0\&synonyms $=0 \&$ query=Intoxication [Accessed 18 June 2021].

12. Attorney General v. Munasinghe - NLR - 241 of 70 [1967] LKCA 15; (1967) 70 NLR 241 (6 Nov 1967) [Accessed 4 June 2021].https:// www.lawnet.gov.lk/wp-content/uploads/2016/ 11/057-NLR-NLR-V-70-The-Attorney-GeneralAppellant-and-KB-Munasinghe-and-3-othersRespondents.pdf [Accessed 18 June 2021]. 